\title{
SUBACUTE CHANGES IN SOME HEMATOLOGICAL AND BIOCHEMICAL INDICES OF RATS TREATED BY TECHNICAL AND $10 \%$ FORMULATION ALPHACYPERMETHRIN
}

\author{
RIZK ALLA, M. M., MADIHA M. TALHA, G. A. ABD EL RAHEIM
}

Central Laboratory of Pesticides, ARC, Dokki, Giza

(Manuscript received 31 May 2009)

\begin{abstract}
In the present study four groups of experimental rats were treated orally for 28 consecutive days with two different doses of technical Alphacypermethrin $96 \%(10.5,5.25 \mathrm{ppm}$ or $1 / 10,1 / 20$ LD50) and two other doses of its formulation $10 \%(1.2,0.6 \mathrm{ppm}$ or $1 / 10,1 / 20$ LD50). Blood samples were obtained from all groups after two weeks of start treatment and at the end of treatment period, then some hematological and biochemical parameters were assayed in blood and plasma, respectively.

Hematological results showed significant increase of RBC's count by the high dose of technical at the end of treatment period and significant increase of $\mathrm{Hb}$ conc. by the two doses after two weeks of treatment and the end of it. Ht \% was increased significantly by the two doses of technical at the end of treatment also MCHC \% was increased significantly by the two doses after two weeks of treatment and by the low dose only at the end of treatment. In case of formulation, the results showed significant decrease in RBC's count by the two used doses and significant increase in WBC's count by the low dose after two weeks of treatment, also significant decrease in $\mathrm{Hb}$ conc. by the two doses after two weeks of treatment and at the end of it. $\mathrm{Ht} \%$ was decreased significantly by the low dose, MCV value was increased significantly by the high dose after two weeks of treatment and $\mathrm{MCH}$ value was decreased significantly by the two doses at the end of treatment period. At last MCHC \% was decreased significantly by the high dose after two weeks of treatment and by the two doses at the end of it. Biochemical results in case of technical showed significant decrease in total protein conc. by the high dose after two weeks of treatment, significant decrease in albumin conc. by the low dose at the end of treatment, significant increase in total cholesterol conc. by the low dose after two weeks of treatment and by the high dose at the end of treatment. Significant increase was noticed in triglycerides conc. by the high dose at the end of treatment and in LDL conc. by the low and high doses after two weeks of treatment and at the end of it, respectively. In case of formulation, significant increase in total protein conc., total cholesterol conc. and triglycerides conc. was noticed after two weeks of treatment by the low dose. At last LDL conc. was significantly increased by the low dose after two weeks of treatment then, decreased significantly by the two doses at end of treatment.
\end{abstract}




\section{INTRODUCTION}

Alphacypermethrin is a highly active pyrethroid insecticide; effective against a wide rang of pests encountered in agriculture and animal husbandry. In mammals it is a neurotoxic compound interacting with the sodium channels in the peripheral and central nervous system (WHO, 1996). Signs of intoxication with alphacypermethrin in 28 and 90 day oral toxicity studies in rats at dose levels of $40 \mathrm{mg} / \mathrm{kg} \mathrm{b.w}$. and above were salivation, high-stepping and splayed gait, hunched posture, hypersensitivity to stimuli, reduced body weight and food consumption (Emea, 2001). In 90 days oral toxicity stud in rats, increase in relative liver weight, decrease in hemoglobin(males), decrease in mean corpuscular volume(MCV males) and decrease in eosinophils (males) were seen $(\mathrm{WHO}, 1998)$.

In this study we investigate some hematological and biochemical changes in male rats treated with two different doses of both technical alphacypermethrin $96 \%$ and its formulation $10 \%$.

\section{MATERIALS AND METHODS}

Chemicals:- Alphacypermethrin ((R)- cyano(3-phenoxyphenyl)methyl (1s,3s)-rel-3(2,2-dichloroethenyl )-2,2-dimethylcyclopropanecarboxlate)technical grade 96\%and its E.C. formulation $10 \%$ (super alpha) were obtained from El-Help Co. (Egypt)and used in this study.

Experimental animals: - Adult male albino rats (Wister strain) weighting 120-150g were used in this study. Animals were acclimatized for 2 weeks prior to study under normal health conditions in the animal house of the Mammalian Toxicology Department, Central Agriculture Pesticides Laboratory, were fed on a normal commercial diet and were allowed free excess of water.

Experimental design: - 25 animals were randomly divided to five groups of equal five rats each. The groups were treated as follows:

Group 1:- The animals were administrated the dose level $10.5 \mathrm{mg} / \mathrm{kg}$ b.w.(1/10LD50) of the technical alphacypermethrin as a high dose.

Group 2:-The animals were administrated the dose level $5.25 \mathrm{mg} / \mathrm{kg}$ b.w.(1/20LD50)of the technical alphacypermethrin as a low dose.

Group 3:- The animals were administrated the dose level $1.2 \mathrm{mg} / \mathrm{kg}$ b.w.(1/10LD50)of the formulation as a high dose.

Group 4:- The animals were administrated the dose level $0.6 \mathrm{mg} / \mathrm{kg}$ b.w.(1/20LD50)of the formulation as a low dose. 
Group 5:- The animals were received distilled water to be used as control. All groups were treated orally by metallic stomach tube for 28 consecutive days.

Blood sampling: - The blood samples were obtained at two periods (14, 28 days) from the retero-orbital plexus of veins according to the method of Schermer(1967). The first sample was collected in clean dry tube containing the anticoagulant substance EDTA (ethylene diamine tetra acetic acid) and used for the hematological studies. The second sample was collected with heparin as anticoagulant and centrifuged at $600 \mathrm{~g}$. for $15 \mathrm{~min}$. then, plasma was separated and kept in a deep freezer at $-20 \circ \mathrm{C}$. until biochemical measurements were carried out.

Hematological parameters:- Red and white blood cells counts(RBC's, WBC's) were done by using the hemocytometer and the total hemoglobin conc. $(\mathrm{Hb})$ was determined according to the method of Wong(1928). Hematocrite value (PCV) was estimated by using the heparinized capillary tubes. The mean corpuscular volume (MCV), the mean corpuscular hemoglobin conc. $(\mathrm{MCH})$ and the mean corpuscular hemoglobin conc. (MCHC) were calculated according to Schalm (1986) as the following equations:-

$\mathrm{MCV}=\mathrm{PCV} / \mathrm{RBC}$ 's $\times 10=\mathrm{Fl}$
$\mathrm{MCH}=\mathrm{Hb} / \mathrm{RBC} \mathrm{S} \times 10=\mathrm{Pg}$
$\mathrm{MCHC}=\mathrm{Hb} / \mathrm{PCV} \times 100=\%$

Biochemical parameters: - Diagnostic kits were obtained from Stabino Co. (Spain) and used for total protein conc. as the method of Henry et al. (1974) and albumin conc. by the method of Doumas and Biggs (1972). Total cholesterol conc. was estimated according to Allain et al. (1974), triglycerides conc. also by the method of Fossati and Prencipe(1982) and low density lipoprotein cholesterol conc. as Okada et al. (1988) method.

Statistical analysis: - Data were expressed as mean \pm SE and significant differences of values were calculated according to the student $t$-test (Snedecor and Cochran, 1970).

\section{RESULTS AND DISCUSSION}

The technical grade of cypermethrin is the racemic mixture of 8 isomers (four cis and four trans). Two stereo isomers are termed alpha, which is believed to be the most active isomer and is known as a- cypermethrin. In this study two different doses of both technical alpha cypermethrin $96 \%$, its $10 \%$ formulation $(1 / 10,1 / 20$ of laboratory determined LD50 from both forms) were tested in male rats and results for some hematological and biochemical parameters were recorded after 14 and 28 days of treatment. 
Tables 1, 2 contain the hematological changes by both used forms of acypermithrin.More significant changes were produced and more parameters were affected by the formulation than the technical. The 28 days effect of the technical was more obvious than the 14 days effect, but in case of formulation the 14 days effect was more obvious. The most interesting notice was that the most significant changes by the formulation were negative or damage indicators (decrease RBC's count, increase WBC's count, decrease $\mathrm{Hb}$ conc., $\mathrm{Ht} \%$, MCV value and MCHC \%), while all significant changes induced by the technical were positive (increase RBC's count, $\mathrm{Hb}$ conc., Ht \%, and MCHC \%). Haratym-Maj (2002) found no subacute changes in RBC's count, $\mathrm{Ht} \% \mathrm{Hb}$ conc. in male mice treated with $5,25 \mathrm{mg} / \mathrm{kg}$ b.w. alphacypermethrin $97.7 \%$.

Tabels 3, 4 showed some biochemical changes that induced by the two used forms of alphacypernethrin in male rats where the technical produced more changes in proteins concs. (14 days significant decrease in total protein conc. by the high dose and 28 days significant decrease in albumin conc. by the low dose) than the formulation (14 days significant increase in total protein conc. by the low dose). The technical also produced 14 and 28 days significant increases in total cholesterol conc. by the low and the high doses respectively, 28 days significant increase in triglycerides conc. by the high dose and 14, 28 days significant increases in LDL conc. by the low and the high doses respectively. The formulation caused 14 days significant increase in total cholesterol, triglycerides and LDL concs. by the low dose and 28 days significant decrease by the two used doses. Manna e al. (2004), (2006) recorded subacute, subchronic significant decreases in total protein, globulin concs. in rats treated by $14.5 \mathrm{mg} / \mathrm{kg}$ b.w. pure alphacypermethrin $99 \%$. These results suggest more hematological damage by the formulation $10 \%$ and more biochemical damage by the technical $96 \%$ in male Wister rats at laboratory conditions. 
148 SUBACUTE CHANGES IN SOME HEMATOLOGICAL AND BIOCHEMICAL INDICES OF RATS TREATED BY TECHNICAL AND 10\% FORMULATION ALPHACYPERMETHRIN 
SUBACUTE CHANGES IN SOME HEMATOLOGICAL AND BIOCHEMICAL INDICES OF RATS TREATED BY TECHNICAL AND 10\% FORMULATION ALPHACYPERMETHRIN 


\section{ACKNOWLEDGMENT}

The authors gratefully acknowledge the assistance and supporting of Dr. Nagy Abd El-salam Ibrahim.

\section{REFERENCES}

1- Allain, C.C., L.S. Poon, C.S.G. Chan, W. Richmond and P.C. Fu. 1974. Enzymatic determination of total serum cholesterol, Clin. Chem., 20 (4), 470-475.

2- Doumas, B.T. and H.G. Biggs. 1972. Determination of serum albumin in standard methods of clinical chemistry. G.A. Copper Ed. New York, Academic Press. Inc. Vol. 7, P.175.

3- Emea, 2001. The European Agency for the Evaluation of Medicinal Products. Committee for Veterinary medicinal products alphacypermethrin summary report (2).

4- Fossoti, P. and L. Prencipe. 1982. Serum triglycerides determination calorimetrically with an enzyme that produces hydrogen peroxide. Clin. Chem., 28(10), 2077-2080.

5- Haratym-Maj, A. 2002. Hematological alterations after pyrethroids poisoning in mice. Ann. Agric. Environ. Med., 9, 199-206.

6- Henry R.J., D.C. Cannon and J.W. Winkelman. 1974. Clin. Chem. Principals and Techniques. Harper and Row Publ., New York, P.415.

7- Manna, S., D. Bhattacharya, T.K. Mandal and S. Das. 2004. Repeated dose toxicity of alphacypermethrin in rats. J. Vet. Sci. 5(3), 241-245.

8- Manna, S., D. Bhattacharya, T.K. Mandal and S. Das. 2006. Sub-chronic toxicity study of alphacypermethrin in rats. Iranian Journal of Pharmacology and Therapeutics, V. 5, N. 2, pp.163-167.

9- Okada, M., H. Matsui, Y. Ito, A. Fujiwara and K. Inono. 1998. Low density lipoprotein cholesterol can be chemically measured: A new superior method. J. Lab. Clin. Med. V. 132(3), pp.195-201.

10- Schalm, O.W. 1986. Veterinary Hematology, Fourth Ed. Lea and Febiger, Philadelphia, p. 21-86.

11- Schermer, S. 1967. The blood morphology of laboratory animals $3^{\text {rd }}$ Ed. Davis FA Co., Philadelphia, p.42.

12- Snedecor, G.W. and W.G. Cochron. 1970. Statistical methods $14^{\text {th }}$ Ed. Iowa State Univ. Press, p.593-598.

13- WHO. 1996. Toxicological evaluation of certain veterinary drug residues in food. Food Additives Series 38, 133-170.

14- WHO. 1998. Evaluation of certain veterinary drug residues in food. Forty seventh report of the joint FAO/WHO expert committee on food additives 1998; 876.

15- Wong, S.Y. 1982. Colorimetric determination of iron and hemoglobin in blood. J. Bio. Chem. 77: 409. 


\section{التغيرات تحت الحادة لبعض المعايير الهيماتولوجية والبيوكيماوية فى الفئران المعاملة بالفاسيبرمثرين الخام ومستحضر 10}

\section{ماجد منصور رزق الله مديحة محمد طلحة غريب عبد المبدى عبد الرحيم \\ قسم بحوث سمية المبيدات للثدييات و الاحياء المائية- المعدل المركزى للمبيد/ت-مركز البحوث الزرباعبة}

فى هذة الدر اسة تم معاملة 4 مجموعات من فئر ان التجارب بتركيزين مختلفين من خام الفا سييرمثرين 96\%(10,5و5,25 جزء في المليون أو 10/1و 20/1من قيمة الجرعة القاتلة النصفية) وتركيزين أخرين من المستحضر 10\% لنفس المبيد(2,1و6,0جزء فئ في المليون أو 10/1و 20/1 من قيمة الجرعة القاتلة النصفية)عن طريق التجريع الفمى ولمدة 28 يوم متو اصلة ثم أخذت عينات الدم من كل المجموعات بعد أسبو عين من بدء المعاملة وفى نهايتها وتم تقدير مجموعة من المعايير

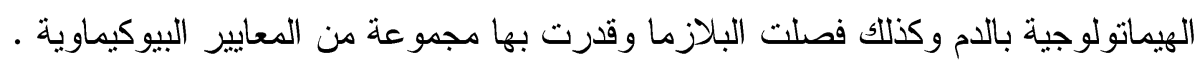
أظهرت النتائج الهيماتولوجية أرتفاع معنوى فى عدد كرات الدم الحمر اء بو اسطة التركيز

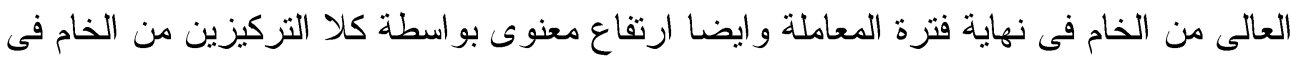

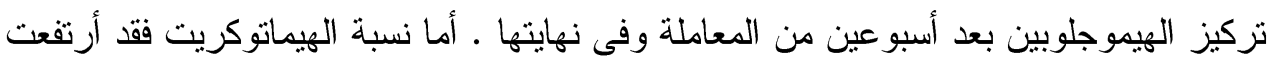

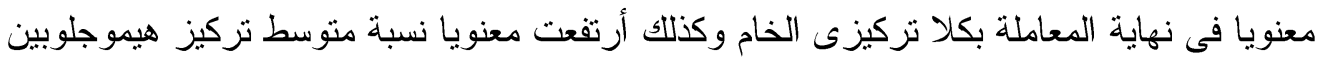
الكرات الحمر اء بو اسطة كلا تركيزى الخام بعد أسبو عين من المعاملة وبالتركيز الاقل فقط فى نهايتها

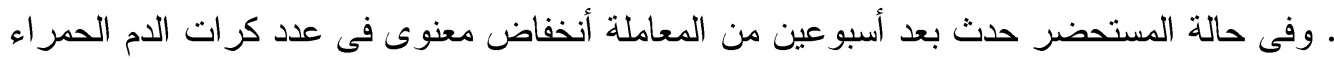

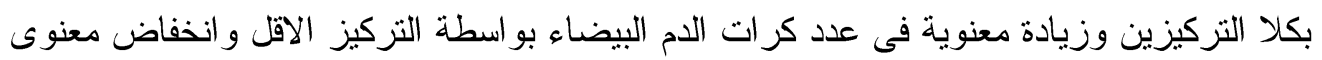

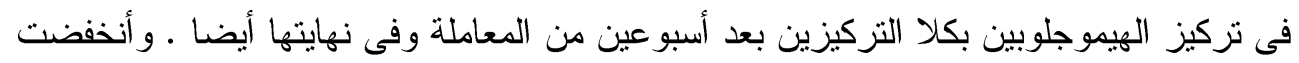

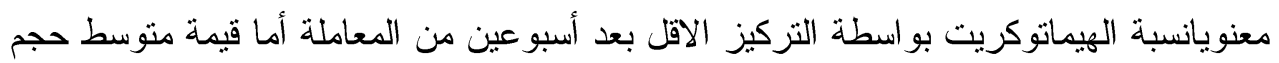

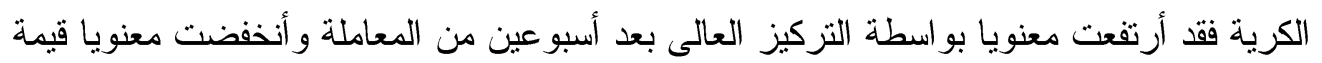

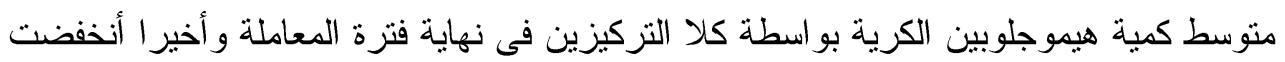

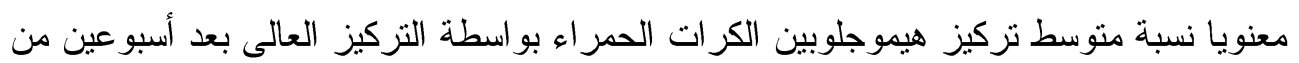
المعاملة وبكلا التركيزين فى نهايتها. أما النتائج البيوكيماوية فقد أظهرت فى حالة الخام أنخفاض معنوى في تركيز البروتين الكلى بو اسطة التركيز العالى بعد أسبوعين و ايضا انخفاض معنوى فى تركيز الالبيومين بو اسطة التركيز

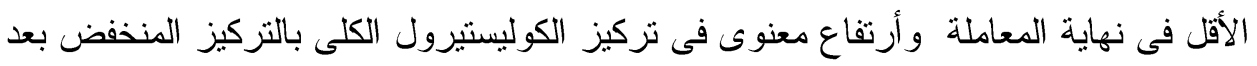
أسبو عين من المعاملة وبالعالى فى نهايتها و أرتفاع معنوى فى تركيز الجلسريدات الثلاثية بو اسطة التركيز العالى فى نهاية المعاملة وفى تركيز الليبوبروتينات منخفضة الكثافة بواسطة التركيز الاقل و

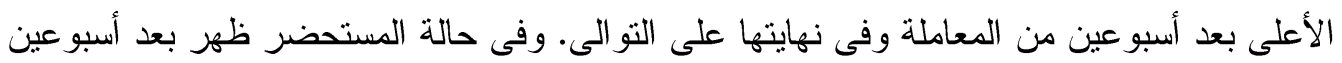

من المعاملة أرتفاع معنوى فى تركيز البروتين الكلى والكوليستيرول الكلى و الجلسريدات الثلاثية فئي بواسطة التزكيز ألأقل واخير ا ارتفع معنويا تركيز الليبوبروتينات المنخفضة الكثافة بواسطة التزكيز الأقل بعد اسبو عين من المعاملة وأنخفض معنويا بكلا التركيزين فى نهايتها. 